\title{
The Impact of Covid-19 on Competitiveness in SMES in Mexico
}

\author{
Martín Iván Martín Puc, Ligia María Bestard Alcántar, Ligia María Río Herrera \\ Facultad de Contaduria y Administracion. Universidad Autonoma de Yucatan, Mexico \\ *Corresponding Authors: Martín Iván Martín Puc, Facultad de Contaduria y Administracion. \\ Universidad Autonoma de Yucatan, Mexico
}

\begin{abstract}
Small and medium-sized enterprises (SMEs) contribute greatly to the sustainability and competitiveness of global, national and local economies; in fact, they are the economic engine of most countries in the world. When no pathways to competitiveness are identified, closure is sure to follow, which in turn leads to rising unemployment and a gradual decline in the standard of living in the country as a whole. The present work aims, through a scientific trial, to identify the effects that the COVID-19 pandemic had on small and medium-sized enterprises (SMEs) in Mexico. The research was descriptive, documentary.
\end{abstract}

Keywords: Competitiveness, SMEs, Covid-19, Yucatan.

\section{INTRODUCTION}

Micro, small and medium enterprises (SMEs) are a very important sector both in Mexico and in the world, in Latin America, it reaches an average of $99.25 \%$ of the total business units, generating 35.5\% of employment, thus fulfilling an important role of leveling economic inequality, which characterizes this region according to Saavedra and Hernández cited by Saavedra and Saavedra (2014), small and medium-sized companies generate 72 percent of jobs in Mexico, the Mexican economy that is measured through of Gross Domestic Product (GDP) contracted 0.1 percent in 2019, this is its first fall in a decade, according to a report from the National Institute of Statistics and Geography (INEGI) cited by the Senate of the Republic (2020) and its projection for this year, which has a reserved nature, is calculated between 0.5 and a maximum 1.5 percent according to the Bank of Mexico cited by the Senate of the Republic (2020), SMEs play a fundamental role for social inclusion, they constitute a determining link in the chain of economic activity and they are essential for regional and local development, in the case of Mexico, according to the National Institute of Statistics and Geography (INEGI) cited by the Senate of the Republic (2020), 4.1 million are SMEs of the total that represents 95.4 percent, of these 3.6 are small and 0.8 are medium enterprises. Their contribution is 52 percent of the Gross Domestic Product (GDP) (Senado de la República, 2020). Small and mediumsized enterprises, SMEs, are particularly important for national economies, not only for their contributions to the production and distribution of goods and services, but also because of the flexibility to adapt to technological changes and their great potential for job creation. They represent an excellent means to promote economic development and a better distribution of wealth (State Commission for Higher Education Planning, A.C., 2015). In Mexico as in other countries, small and medium-sized enterprises (SMEs) have great importance in the economy, since they provide the largest number of economic units and employed personnel, according to data reported by the National Institute of Statistics and Geography (INEGI) cited by Luna, Salgado, Cuevas and Barrios (2016), Small and medium-sized enterprises (SMEs), constitute in any country, the predominant group of companies, in some cases they exceed $99 \%$ of economic units, they contribute significantly to the creation of employment, the generation of wealth and also satisfy needs in certain markets that are not very attractive for large companies. They are also the crucible in which great entrepreneurs are formed and the vehicle for the self-development of millions of people, according to Ansriani, Biasca, and Rodríguez cited by Gómez, Salcido, Luján and Meléndez (2015), SMEs are linked to large companies both in a more efficient production and distribution, with an intensive workforce, with lower labor costs, while large companies incorporate innovation and technological development to increase productivity, be more competitive and expand external markets (González, 2021), SMEs are 
important because in most countries they represent more than $90 \%$ of establishments, and in Mexico they reach up to $99 \%$ of companies and generate $70 \%$ of employment and national wealth (González, 2021), the importance of SMEs lies in the fact that small businesses can help reduce poverty in countries, since they generate large amounts of employment, appropriate levels of job quality and low cost of goods and services used by the poor according to Vanderberg cited by Saavedra and Saavedra (2014).

From the pandemic generated by COVID-19, with its dire economic consequences, it has generated a financial problem that has led many businesses to close or, in the best of cases, to innovate their structure. Governments of some Latin American countries have begun to announce some relief measures for SMEs in the midst of quarantine and a stoppage of commercial activity, in some cases there is been almost no result; this situation represents a challenge for business finances (Durán, 2020). The pandemic caused by COVID-19, has generated an economic problem and has significantly deteriorated the prospects that small and medium-sized enterprises (SMEs) had of achieving growth (Durán, 2020). The International Monetary Fund (IMF) and the Economic Commission for Latin America and the Caribbean (ECLAC), both cited by Duran (2020), estimate that Mexico's growth during 2020 will be around-6. 6\%. Despite the impact of the pandemic on the economy, Mexico is one of the countries in Latin America and the world that has allocated the least resources to support the private sector and, according to an analysis by the Economic Commission for America In Latin America and the Caribbean (ECLAC), the Mexican government has allocated support and credits for companies and businesses equivalent to $3.8 \%$ of the Gross Domestic Product (GDP), compared to Chile, which has allocated $11.4 \%$, Colombia $8 \%$, Peru $7.6 \%$, Uruguay $5.3 \%$ and Costa Rica $4.3 \%$. This strategy of the Mexican government had clear consequences in the financial situation of SMEs (Durán, 2020).As a result of the contingency due to COVID-19, an unprecedented crisis is anticipated, where the most vulnerable companies will be small and medium-sized (SMEs), warned the president of the National Chamber of the Transformation Industry (CANACINTRA) Enoch Castellanos, cited by Guarded, Martínez and Tapia (2020), stating that there is no company that can strive more than a month and a half if their sales drop suddenly, in Mexico SMEs represent $98.8 \%$ of companies, as well as $71 \%$ of the jobs in the country according to Salgado and Pérez cited by Ramírez (2017), so their impact on the economy is fundamental, generating 52\% of GDP (Ramírez, 2017). The present work aims, through a scientific trial, to identify the effects that the COVID-19 pandemic had on small and medium-sized enterprises (SMEs) in Mexico.

\section{DEVELOPING}

\subsection{Small and Medium-Sized Enterprises in Mexico}

In 2015, the National Institute of Statistics and Geography (INEGI) and the National Bank of Foreign Trade (Bancomext) designed the National Survey of Productivity and Competitiveness for Micro, Small and Medium Enterprises (ENAPROCE). The survey reached 26,997 enterprises but only 14\% of these firms exported to the international market, and less than $2 \%$ invested in innovation that leads to patent or brand registration. (INEGI, 2015)

In 2018, in order to update information on the SMEs, the survey was once more conducted and this time it reached 22,188 enterprises, where 18,886 were SME's. The study provided information mainly from 2017 related to the sources and conditions of access to financing, global production chains, innovation and technology capacities, the business environment and its regulation, as well as knowledge of government support, among other topics.

The activities carried out by the enterprises were: manufacturing, trade and groups of specific sectors of private non-financial services. (INEGI, 2018).

According to INEGI (2018), there were 113, 036 Small- and Medium-sized Enterprises. This survey revealed that $55.1 \%$ of SMEs provided their employees with training and $28.2 \%$ used 3 to 5 key performance indicators to assess their achievements, while $8.8 \%$ considered 10 or more performance indicators. In order to accomplish their goals, $34.3 \%$ took actions to foster continuous improvement and $39.3 \%$, to avoid possible problems.

$39.8 \%$ of SMEs declared they would accept government support and financial assistance, but only $23.2 \%$ has access to them. 
In 2018, the average interest rates varied according to the amounts of the loans and the size of the borrowing company. For SMEs, the average interest rate was approximately was $17.70 \%$. (OECD, 2020)

\subsection{Competitiveness of SME's}

In Mexico there are 4 million SMEs, of which $97.4 \%$ are microenterprises that represent $12.4 \%$ of total gross production (TGP) and employ $47.2 \%$ of the workforce. (OECD, 2020)

According to the Global competitiveness index of 2016-17 (Schwab, 2016) and 2017-18 (Schwab, 2017), Mexico advanced from the 57th to the 51st rank on a total of 138 countries in 2016-17, and remained at that rank in 2017-18.

In 2019, according to Schwab (2019), Mexico advanced to the 48th rank, with a score of 64.9 (scale rates from 0 to 100). On the other hand, INEGI (2018) revealed that only $4.6 \%$ of SMEs participated in Global Value Chains (GVCs) during 216-2017, meaning that most operations and production processes are developed at a national scale.

$28.4 \%$ of the enterprises that are involved in GVCs argued they are interested in participating because they give them access to other markets and 19\% declared GVCs allow them to gain stability when it comes to demand and prices.

\subsection{Effects of COVID on SMEs in Mexico}

The economic impact of COVID-19 in Mexico began to be observed in March, it brought unexpected situations such as the closure of operations, companies and non-essential organizations, and also the development of the pandemic in Latin America was subsequently noticed by others regions of the world, Mexico is initially affected by the economic relations it has with countries abroad (Pastor and Laredo, 2020). From the pandemic, taking into account the economic consequences of closing many businesses considered "non-essential", a financial problem was generated that has led many companies to close or, in the best of cases, to rethink their structure (Duran, 2020). According to the National Institute of Statistics and Geography (INEGI, 2021), GDP (Gross Domestic Product) grew by $0.8 \%$ in real terms during the first quarter of 2021; compared to the second quarter of 2020, which had a decrease of $17.3 \%$ compared to the previous quarter of that same year, which was when the pandemic began and approximately $86 \%$ of companies and businesses considered "non-essential" were closed (Téllez, 2021). Considering the above, later in 2021 the great benefit obtained can be observed, due to the fact that the government decided to open companies and businesses with these activities, starting with the opening gradually; The $8 \%$ annual fall for that quarter would be the optimistic scenario and the $12 \%$ fall would be the pessimistic scenario. In the same sense, it can be anticipated that, if the gradual reopening of the economy continues, the fall in the fourth quarter could still be between 4 and 8\% compared to the same quarter of the previous year (Esquivel, 2020). Although the governments of the main countries that have been affected by the COVID-19 crisis have taken and promoted measures to mitigate the economic slowdown caused by this virus, it is observed that its spread could have a triple effect on the world economy: direct impact on production volumes globally; disruptions to supply and distribution chains; and financial impact on organizations, companies and the securities markets, (Huicalpi, Troya and Ocampo, 2020).

Before June, production in the mining, construction, automotive and aerospace sectors became "nonessential activities" and it was decided to stop all these activities in Mexico. The falls of $25 \%$ and $14 \%$ in the production of industrial and service sectors translated into a decrease of $17.3 \%$ in the IGAE of Mexico compared to March, which is the largest monthly reduction throughout history, (Yan, 2021). In relation to data from the Economic Commission for Latin America and the Caribbean (ECLAC), the pandemic caused by Covid-19 will affect the world economy more intensely than the crisis of 2008-2009 (Hu, Kumul and Xool, 2020). The Mexican economy will have to respond immediately to new and unavoidable productive, social and environmental demands. There are the conditions of possibility: the shortening of international value chains, the return to protectionism in central countries and the need to find self-sufficiency in essential products for health and food (Pizarro, 2020). 


\section{CONClusions}

The reduction of mobility can help to contain the spread of the virus but it also shows collateral damage which is represented in an economic crisis. In other words, the world goes from a moment of health crisis to an economic crisis, this is the greatest fear of current capitalism and more so in the case of SMEs.

The pandemic has hit Mexico in the midst of a business environment for SMEs regarding the use of technological resources, innovation, ability to meet business objectives and to solve problems in production processes.

The effects on companies are generalized, however, the pandemic mainly affects SMEs, which make up the majority of production units in Mexico. Among the main consequences are: reduction of income, drop in demand, shortage of inputs, cutbacks in personnel, reduction of salaries and benefits.

As part of the health measures, most of the companies resorted to a temporary shutdown, that joined to the effects of the pandemic, as well as a dropin consumer confidence, have an impact on their liquidity, which makes it necessary for them to be helped through money transfers or postponing immediate obligations. However, support for companies is minimal and a large majority are yet to receive any.

Finally, it is important to mention that the most affected are small and medium-sized companies which have already shown problems due to their structural conditions and with these problems of adaptation to a new normal, not all of them manage to survive this crisis, therefore the government must support and attend to this business sector. There is no doubt that COVID-19 will continue to remain among humanity, which is why the business sector must place great emphasis on healthy distance measures and adapt to new forms of business.

\section{REFERENCES}

Comisión Estatal para la Planeación de la Educación Superior, A.C. (2015) Importancia de las Pymes en México. Disponible en: http://www.noticiascoepesgto.mx/the-news/255-pymesroque

Durán, M. (2020) El impacto de la crisis sanitaria generada por COVID-19 en las pequeñas y medianas empresas (Pymes) de Hermosillo Sonora. Revista de investigación académica Sin Frontera. No 34, pp. 121Available at:https://revistainvestigacionacademicasinfrontera.unison.mx/index.php/RDIASF/article/view/357/325

Esquivel, G. (2020). Los impactos económicos de la pandemia en México. Revista Economía UNAM, Vol 17 No 51,pp. 1-17. DOI: https://doi.org/10.22201/fe.2448814e.2020.51.543

Gómez, P., Salcido, D., Luján, L., Meléndez, R. (2015) Globalización y Logística: importancia para las pymes.Revista de Negocios y pymes, Vol 1 No 1, pp. 14-28,Available at:https://www.ecorfan.org/spain/ researchjournals/Negocios_y_PyMES/Revista\%20de\%20Negocios\%20\&\%20PYMES.pdf

González, G. (2021) La importancia de las mipymes en el desarrollo del capitalismo en México. México: UNAM.

Guardado, S., Martínez, J., Tapia, D. (2020) COVID-19 en México: repercusiones y retos del factor humano, financiero y fiscal. Ciencia, Economía y Negocios. Vol 4 No 2, pp. 5-32, Doi: 10.22206/ceyn.2020 .v4i2.pp5-32

Hu, G.; Kumul, C.; Xool, R.; Sánchez, M (2020). El emprendimiento y sus impactos en la economía por la pandemia Covid-19. Revista Educiencia. Vol 6 No 10, pp. 20-3. Available at:https://educiencia.uat.edu. mx/index.php/Educiencia/article/view/196/132

Huicalpi, N.; Troya, K. Ocampo, W (2020). Impacto del COVID -19 en la planeación estratégica de las pymes ecuatorianas. Revista Cientifica Mundo de la Investigación y el Conocimiento, Vol 4 No 3, pp. 1-10. DOI: 10.26820/recimundo/4.(3).julio.2020.76-85.

Instituto Nacional de Estadística y GeografíaINEGI (2015). Encuesta Nacional sobre Productividad y Competitividad de las Micro, Pequeñas y Medianas Empresas.Available at:https://www.inegi.org.mx/ contenidos/programas/enaproce/2015/doc/ENAPROCE_15.pdf

Instituto Nacional de Estadística y GeografíaINEGI (2018). Encuesta Nacional sobre Productividad y Competitividad de las Micro, Pequeñas y Medianas Empresas. Available at:https://www.inegi.org.mx/ contenidos/programas/enaproce/2018/doc/ENAPROCE2018Pres.pdf 
Instituto Nacional de Estadística y geografía INEGI (2021) Producto Interno bruto de México durante el primer trimestre del 2021 en México, Available at:https://www.inegi.org.mx/contenidos/saladeprensa/boletines/ 2021/pib_pconst/pib_pconst2021_05.pdf

Luna, F. , Salgado, A., Cuevas, B.,Barrios, G.(2016)Ciclo de Vida Organizacional en las MiPymes Mexicanas, Ramo Maderero.Revista de Negocios y pymes, Vol 2 No 4, pp. 1-8, Available at: https://www.ecorfan.org/ spain/researchjournals/Negocios_y_PyMES/vol2num4/Revista_de_Negocios_\&_PYMES_V2_N4_1.pdf

OECD (2020), Financing SMEs and Entrepreneurs 2020: An OECD Scoreboard, OECD Publishing, Paris. Available at:https://www.oecd-ilibrary.org/sites/c2314a63-en/index.html?itemId=/content/component/ c2314a63-en

Pastor, A. Laredo, A. (2020). El impacto del COVID-19 en la Economía Mexicana. Boletín Económico de ICE Información Económica Española, No 3130, pp . 19-35. Available at: http://www.revistasice.com/ index.php/BICE/article/view/7134/7155

Pizarro, R (2020). Un paso de Julio)mas allá de la COVID-19. Revista Scielo El trimestre económico, Vol 87 No 3484, pp. 1033-1057. Available at:https://www.eltrimestreeconomico.com.mx/index.php/te/ article/view/1174

Ramírez, A. (2017) Los factores de la competitividad en las MiPymes en México.Disponible en : https://www. pag.org.mx/index.php/PAG/article/view/663

Saavedra, G., Saavedra, G. (2014) La PYME como generadora de empleo en México.Revista Clío América, Vol 8 No 16, pp. 153-172, Available at: http://revistas.unimagdalena.edu.co/index.php/clioamerica/ article/view/1350/760

Schwab, K. (2016).The Global Competitiveness Report 2016-2017. Geneva: World Economic Forum.

Schwab, K. (2017).The Global Competitiveness Report 2017-2018. Geneva: World Economic Forum.

Schwab, K. (2018) The Global Competitiveness Report 2018. Geneva: World Economic Forum.

Schwab, K. (2019) The Global Competitiveness Report 2019. Geneva: World Economic Forum.

Senado de la República (2020)Pymes, importante motor para el desarrollo económico nacional: MC. Available at:.http://comunicacion.senado.gob.mx/index.php/informacion/boletines/47767-pymes-importante-motorpara-el-desarrollo-economico-nacional-mc.html

Téllez, C. (2021). Reabre 86\% de Empresas que cerraron durante la pandemia. El Financiero Periodico digital. Available at:https://www.elfinanciero.com.mx/economia/2021/06/29/reabre-86-de-las-empresas-cerradasdurante-la-pandemia/

Yan, L. (2021). Reflexiones acerca del impacto de la crisis del coronavirus sobre las Mipymes Mexicanas. Revista del Centro de estudios China-Veracruz/Universidad Veracruzana. Vol 10 No 21, pp. 2-22. Available at:https://orientando.uv.mx/index.php/orientando/article/view/2665/4640

\section{AUTHORS' BIOGRAPHY}

Martin Ivan Martin Puc, Full time professor in the Facultad de Contaduría y Administración, UADY. Independent Consultant, PhD in Taxation Sciences, Instituto de Especialización para Ejecutivos. M.S. in Taxation, Instituto de Especialización para Ejecutivos, B.S. in Public Accounting, Universidad Autónoma de Yucatán (UADY). Facultad de Contaduría y Administración, Universidad Autónoma de Yucatán (UADY).

Ligia María Bestard Alcántar, Full time professor in the Facultad de Contaduría y Administración, UADY, Tizimin Mulitidisciplinary Unit. M.Ed, UNID. B.S. in Public Accounting: Universidad Autónoma de Yucatán (UADY).

Ligia María Río Herrera, Full timeprofessor in the Facultad de Contaduría y Administración (FCA, UADY). M. Ed in Innovation, Universidad Autónoma de Yucatán (UADY). B.S. in Public Accounting, Universidad Autónoma de Yucatán (UADY).

Citation: Martín Iván Martín Puc, et.al, "The Impact of Covid-19 on Competitiveness in SMES in Mexico" International Journal of Managerial Studies and Research (IJMSR), vol 9, no. 8, 2021, pp. 22-26. doi: https://doi.org/10.20431/2349-0349.0908004.

Copyright: () 2021 Authors. This is an open-access article distributed under the terms of the Creative Commons Attribution License, which permits unrestricted use, distribution, and reproduction in any medium, provided the original author and source are credited. 